Original article

\title{
Factors associated with preventive behaviors, anxiety among healthcare workers and response preparedness against COVID-19 outbreak: A one health approach
}

\author{
Francis Enenche Ejeh ${ }^{\mathrm{a}, *}$, Samuel Owoicho ${ }^{\mathrm{c}}$, Adamu Saidu Saleh ${ }^{\mathrm{b}}$, Laura Madukaji ${ }^{\mathrm{d}}$, \\ Kenneth O. Okon ${ }^{\mathrm{e}}$ \\ ${ }^{a}$ Department of Veterinary Microbiology, Faculty of Veterinary Medicine, University of Maiduguri, Nigeria \\ ${ }^{\mathrm{b}}$ Department of Veterinary Public Health \& Preventive Medicine, Faculty of Veterinary Medicine, University of Maiduguri, Nigeria \\ ${ }^{\mathrm{c}}$ Nigerian Field Epidemiology and Laboratory Training Program, Nigeria \\ ${ }^{\mathrm{d}}$ Department of TB/HIV, APIN Public Health, Nigeria \\ e Department of Medical Microbiology, Federal Medical Centre, Makurdi, Nigeria
}

\section{A R T I C L E I N F O}

\section{Keywords:}

Coronavirus

National response preparedness

Nigeria

SARS-CoV-2

Pandemic

\begin{abstract}
A B S T R A C T
Background: Severe acute respiratory syndrome coronavirus-2 (SARS-COV-2) is the causative agent of COVID-19. This study aimed to assess the preventive behavior, and responses to national preparedness and response readiness to the COVID-19 outbreak by Healthcare workers in Nigeria.

Methods: A cross-sectional survey of $1200 \mathrm{HCW}$ was carried out, three hundred and forty-six (346) responded to the online questionnaire on demographic characteristics, national preparedness, and preventive behavior towards COVID-19 by HCWs. Descriptive analysis of variables in the form of tables and graphs was carried out. A binary logistic regression analysis was applied and expressed as odds ratio (OR) at a 95\% confidence interval (C.I) and p-value of 0.05 as significant values.

Results: Of the (346) HCWs, $249(72.0 \%)$ were males, 214 (61.8\%) belong to the age group 30-39 years, age group of between 20 and 49 years were more likely to be anxious about been infected of SARS-CoV-2. HCWs in the S.E. region were 35 times more likely to use a face mask (OR 35.0; 95\% C.I 3.48-370.41; P = 0.0003), and $140(40.5 \%)$ of the HCWs supported one health approach for containing the spread of COVID-19. HCWs were anxious (OR $=5.885 ; 95 \%$ C.I: $1.634-20.973 ; \mathrm{p}=0.007$ ) about their families becoming infected with SARS-CoV2 because of their occupation.

Conclusion: The national preparedness and response to the COVID-19 outbreak in Nigeria were below expectations. Healthcare workers were worried about infection with SARS-CoV-2. One health approach is recommended for the fight against the infectious disease of animal origin like COVID-19.
\end{abstract}

\section{Introduction}

The 2019 novel coronavirus, which was called severe acute respiratory syndrome coronavirus-2 (SARS-COV-2), is the causative agent of coronavirus disease 2019 (COVID-19). ${ }^{1}$ The disease was declared a public health emergency of international concern (PHEIC) on 30th January $2,020 .^{2,3}$ Since then, over 11 million cases and 530,000 deaths had been reported globally. In Africa, the total number of cases of COVID-19 was 451,129 , while the number of deaths was 10,928 . Nigeria had 27,564 cases of COVID-19 with 6280 death and third in Africa at the time of writing this article. ${ }^{4,5}$ The low cases of COVID-19 in Nigeria may be under-reported due to low testing capacity. ${ }^{5}$ Currently, Nigeria is experiencing ongoing community transmission of SARS-COV-2 from asymptomatic individuals across the various states. Furthermore, there has been an increase in the number of daily reports of the cases of COVID-19. ${ }^{5}$

The direct impacts of COVID-19 in Nigeria include widespread economic and community lockdown. These resulted in increased poverty among the masses. The elites were affected by the restriction on international travel, and some of them depend on medical services overseas. The direct impact of COVID-19 on healthcare workers is the risk of exposure to the hazards of COVID-19 infection.

\footnotetext{
* Corresponding author. Department of Veterinary Microbiology, Faculty of Veterinary Medicine, University of Maiduguri, Nigeria.

E-mail addresses: enenchefrancis@yahoo.com, enenchefrancis@unimaid.edu.ng (F.E. Ejeh).
} 
SARS-COV-2 is transmission via droplet aerosol, from sneezing, coughing, and talking. Other means of transmission include contaminated surfaces, and person to person contacts. ${ }^{6,7}$ Person to person transmission through the routes mentioned above make it easy for the virus to spread within the community. Factors that are responsible for the spread of the disease are overcrowding, lack of isolation facilities, and environmental contamination. Lack of awareness on the preventive measures against COVID-19 may also contribute to the increase in COVID-19 cases among HCWs. ${ }^{8-10}$

Healthcare workers are at the frontline in the fight against COVID19. Thus they are at increased risk of SARS-COV-2 infection. ${ }^{11,12}$ In addition to the hospital or nosocomial acquired infection, HCWs may become infected from the community and transmit the disease to vulnerable people under their care. Likewise, HCWs who become infected may be a source of infection to their friends and family members. ${ }^{13,14}$ Because COVID-19 is new, there is a lack of prospective data that will guide the government and stakeholders addressing the need of HCWs to competently and effectively respond to the spread of SARS-COV-2.

This study aimed to access the preventive behavior, anxiety, and responses relating to national preparedness and response readiness in respect to the COVID-19 outbreak by Healthcare workers in Nigeria.

\section{Methodology}

A cross-sectional study was carried out among healthcare workers in Nigeria, West Africa, in April 2020. The submission of the answered questionnaires was considered as consent to participate in the study. The questionnaire was made available to the participants through social media (WhatsApp, Instagram, Facebook, and Tweeter). The questionnaire was pre-evaluated for consistency and error. Corrections from the participants were considered and integrated into the final questionnaire while ensuring its consistency with the published literature. The reliability coefficient was calculated using SPSS v.16. The value of Cronbach's alpha was found to be $0.7 .^{15}$ The data from the pre-evaluation or pilot study was not included in the final analysis. We sent the survey questionnaires to $1200 \mathrm{HCWs}$ via social media. Three hundred and forty-six (346) participants accepted and completed the questionnaires.

\subsection{Ethical permit and consent note}

The research ethics committee of the Borno State Hospital Services, Ministry of Health, Maiduguri, Nigeria, approved our study protocol (HREC/03/2020/00022). A consent note was not required. The submission of the online answer to the questionnaire was considered as consent to take part in the study.

\subsection{The questionnaire}

Data were collected using an online (Google form) self-administered questionnaire. The questionnaire consisted of four parts. Below is a brief description of the questionnaire:

Part one (1). Demographic characteristics of respondents. Demographic variables included gender, age category, religion, years of experience in healthcare services, the region of residence, and speciality.

Part two (2). National preparedness. This part consisted of eight (8) questions. The questions focused on government policies such as the composition of COVID-19 task force or committee, One health initiative, provision of palliative for the poor and less privileged, adequate provision of medical equipment such as test kits, isolation centers, respirators, and other essential equipment for the Healthcare workers. We employed a Likert scale (Strongly agree, agree, neutral, disagree, and strongly disagree) and dichotomous questions (yes or No) to assess the opinions of HCWs on the national preparedness of the Federal government of Nigeria in response to COVID-19 outbreak.

Part three (3). Preventive behavior of healthcare workers towards
Table 1

Socio-demographic Characteristics of Healthcare Workers $(n=346)$ participated in the Study regarding Knowledge, Attitudes, and Practices.

\begin{tabular}{|c|c|c|}
\hline Variables & Frequency (n) & Percentage (\%) \\
\hline \multicolumn{3}{|l|}{ Sex } \\
\hline Male & 249 & 72.0 \\
\hline Female & 97 & 28.0 \\
\hline \multicolumn{3}{|l|}{ Age categories } \\
\hline $20-29$ & 36 & 10.4 \\
\hline $30-39$ & 214 & 61.8 \\
\hline $40-49$ & 75 & 21.7 \\
\hline $50-59$ & 21 & 6.1 \\
\hline$>59$ & 0 & 0 \\
\hline \multicolumn{3}{|l|}{ Marital Status } \\
\hline Married & 242 & 69.9 \\
\hline Unmarried & 104 & 30.1 \\
\hline \multicolumn{3}{|l|}{ Experience (years) } \\
\hline $0-5$ & 88 & 25.4 \\
\hline $6-10$ & 145 & 41.9 \\
\hline $11-15$ & 58 & 16.8 \\
\hline $16-20$ & 16 & 4.6 \\
\hline $21-25$ & 16 & 4.6 \\
\hline $26-30$ & 9 & 2.6 \\
\hline$>30$ & 14 & 4.0 \\
\hline \multicolumn{3}{|l|}{ Religion } \\
\hline Christianity & 244 & 70.0 \\
\hline Islam & 96 & 27.7 \\
\hline No religion & 6 & 1.7 \\
\hline \multicolumn{3}{|l|}{ Geographical zone } \\
\hline Northcentral & 104 & 30.1 \\
\hline Northeast & 113 & 32.7 \\
\hline Northwest & 30 & 8.7 \\
\hline Southeast & 27 & 7.8 \\
\hline South-south & 37 & 10.7 \\
\hline Southwest & 35 & 10.1 \\
\hline \multicolumn{3}{|l|}{ Specialty } \\
\hline Medical doctor & 67 & 19.4 \\
\hline Veterinary doctor & 120 & 34.7 \\
\hline Public health officers & 49 & 14.2 \\
\hline Nurses & 22 & 6.4 \\
\hline Pharmacist & 16 & 4.6 \\
\hline Medical laboratory scientist & 20 & 5.8 \\
\hline Others & 52 & 15.0 \\
\hline
\end{tabular}

COVID-19. The questions in this part covered the issue of personal behavior concerning the use of protective equipment, and observation of preventive measures by healthcare workers. Two dichotomous questions were used to assess the preventive behavior of HCWs towards COVID-19.

Part four (4). This part raised issues of concern about the safety of healthcare workers and their family while on duty and provision of life insurance in case of permanent occupational hazards. The questions in this category include (1) Do you think you are at risk of COVID - 19 virus infection? (2). Do you believe that your family is at risk of COVID-19 because of your profession?

\subsection{Statistical analyses}

Data were entered in Microsoft Excel and later imported into SPSS version.16 for statistical analysis. Descriptive statistical methods were used to summarize data on socio-demographic characteristics, and responses to questions regarding preventive behavior, anxiety, and responses relating to national preparedness and response readiness in respect to the COVID-19 outbreak in Nigeria by Healthcare workers. Data were summarized as frequencies (n) and percentages (\%) for categorical variables. Furthermore, we presented the data in tables and graphs. To find possible determinants of preventive behavior, and anxiety, a binary logistic regression analysis was applied and expressed as odds ratio (OR) and $95 \%$ confidence interval (C.I). A p-value of less than 0.05 was considered significant in all tests. 


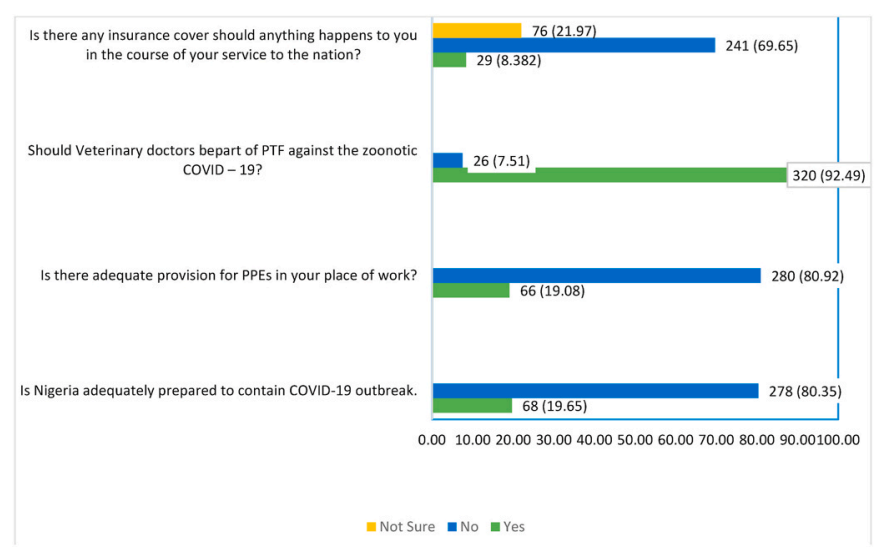

Fig. 1. Healthcare workers responses regarding Response readiness and use of PPE concerning COVID-19 outbreak in Nigeria.

\section{Results}

\subsection{Demographic characteristics of study participants}

Three hundred and forty-six (346) healthcare workers in Nigeria participated in this survey. Table 1 showed the demographic characteristics of the study participants. More than two-thirds of the respondents were male $249(72.0 \%), 214(61.8 \%)$ belong to the age group $30-39$, those that had worked for 6-10 years in healthcare services were 145 (41.9\%), HCWs in the Northeast and North Central Nigeria were $113(32.7 \%)$ and $104(30.1 \%)$ respectively. Veterinary doctors were 120 (34.7\%), while Medical doctors represent 67 (19.4\%).

\subsection{National preparedness and emergency response to COVID-19 outbreak in Nigeria}

Majority 140 (40.5\%) of the HCWs believe that one health approach is the best approach to contain the spread of COVID-19. Also, 120 $(34.7 \%)$ of the respondents agreed that the FGN should seek foreign assistance to combat the COVID-19 outbreak while 45 (13.0\%) disagreed on the same need. Concerning palliative and emergency response to vulnerable people, majority $104(30.1 \%)$ of the HCWs strongly disagreed, and $105(30.4 \%)$ disagree that the FGN provided one in their community.

The majority of the HCWs agreed that there is no provision of insurance in the course of their service while about $22 \%$ of the respondents were no sure. More than $92.5 \%$ of the HCWs held that veterinary doctors be part of the PTF against the zoonotic COVID-19 in the country. The majority $(80.4 \%)$ of the HCWs disagree that Nigeria is prepared to contain the COVID-19 outbreak. All the details are presented in Figs. 1 and 2 .

\subsection{Factors associated with preventive measures against COVID-19} infection among healthcare workers in Nigeria

Out of the many factors line listed to be associated with COVID-19 preventive behaviours among HCWs in Nigeria; age, working experience in the health sector and geographical locations of the HCWs appears to be the only significant $(p<0.05)$ factor associated with preventive behaviours by HCWs against the disease in Nigeria.

The associated factors analysis revealed that those within the age group 20-29 were less likely (OR $=0.02$; 95\% C.I: 0.001-0.635; P = 0.027 ) to observe protective measures against COVID-19. Those with $0-5$ and 6-10 years working experience in health facilities are 105 times and 24 times more likely to observe protective measures against COVID19 , respectively, than those with long years of working experience (reference group, $\mathrm{OR}=1$ ). With regards to the geopolitical zones of the HCWs, those from the S.E. region were 35 times more likely to use a face mask (OR 35.0; 95\% C.I 3.48-370.41; P = 0.0003) than the HCWs from the Southwest (reference epicentre, $\mathrm{OR}=1$ ).

Healthcare workers who strongly agreed that people should avoid large crowds to prevent the spread of SARS-CoV-2 were seven times more likely ( $\mathrm{OR}=6.939 ; 95 \%$ C.I: $2.567-18.759 ; \mathrm{P}<0.001$ ) to wear a face mask when leaving home than those who strongly disagreed (ref.). Families of HCWs who held that SARS-CoV-2 is not a biological weapon were about ten times more likely ( $\mathrm{OR}=9.787 ; 95 \%$ C.I: $2.379-40.265$; $\mathrm{P}=0.002$ ) to observe preventive measure against the spread of COVID19 than those who held that SARS-CoV-2 is a biological weapon. Similarly, those who had confidence that the medical scientist in Nigeria will overcome COVID-19 pandemic were about six times more likely $(\mathrm{OR}=$ 5.769; 95\% C.I: 1.635-20.354; P 0.006) to wear a face mask when leaving home than those who do not have confidence in the medical scientist (Table 2).

\subsection{The anxiety of healthcare workers about COVID-19 outbreak in Nigeria}

On the concern of healthcare workers in this survey, those within the age bracket: $20-29,30-39$ and $40-49$ years were more likely to be anxious that they would become infected with of SARS-CoV-2, having

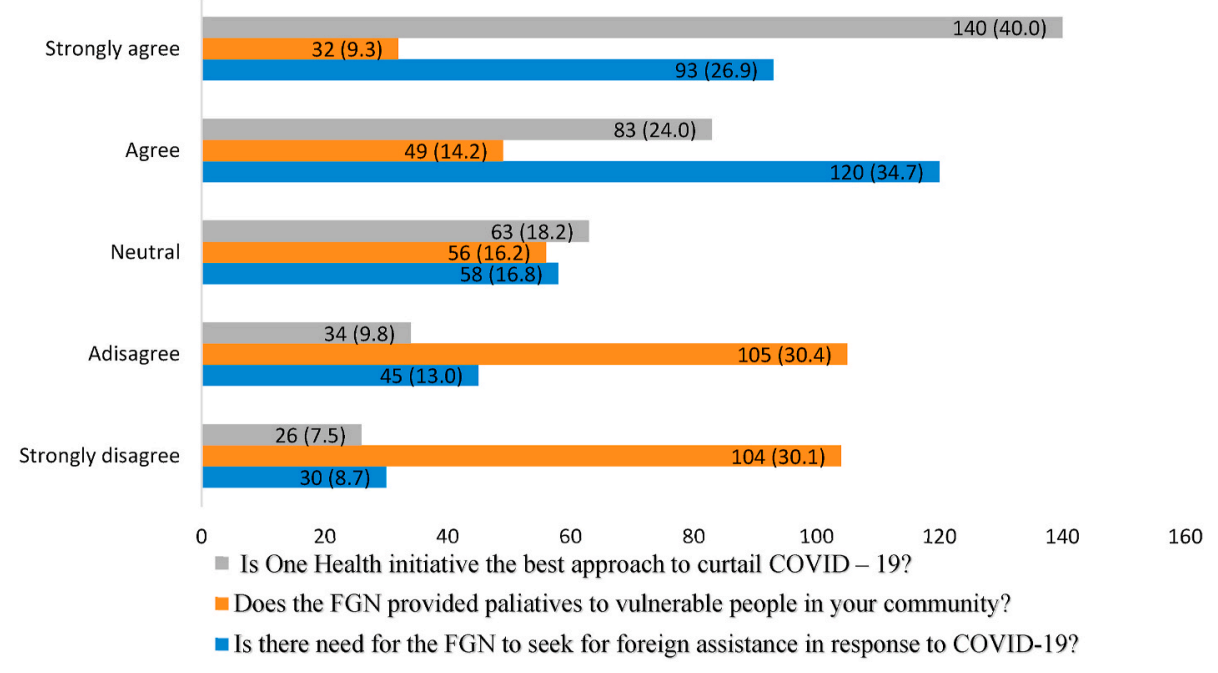

Fig. 2. Response of Healthcare Workers for National Preparedness and Response to COVID-19 outbreak in Nigeria. 
Table 2

Factors associated with preventive behavior against COVID-19 by healthcare workers in Nigeria.

\begin{tabular}{|c|c|c|c|c|}
\hline Variables & $\begin{array}{l}\text { Wearing } \\
\text { of Face } \\
\text { mask }\end{array}$ & $\begin{array}{l}95 \% \mathrm{C} \cdot \mathrm{I}(\mathrm{P} \\
\text { Value) }\end{array}$ & $\begin{array}{l}\text { Washing } \\
\text { hands, and } \\
\text { social } \\
\text { distancing }\end{array}$ & $\begin{array}{l}95 \% \mathrm{C} \cdot \mathrm{I}(\mathrm{P} \\
\text { Value) }\end{array}$ \\
\hline \multicolumn{5}{|l|}{ Gender } \\
\hline Male & 0.810 & $\begin{array}{l}0.414-1.582 \\
(0.537)\end{array}$ & 0.526 & $\begin{array}{l}0.199-1.395 \\
(0.197)\end{array}$ \\
\hline $\begin{array}{l}\text { Female } \\
\text { Age group }\end{array}$ & 1 & - & 1 & - \\
\hline $20-29$ & 1.543 & $\begin{array}{l}0.188-12.489 \\
(0.689)\end{array}$ & 0.020 & $\begin{array}{l}0.001-0.635 \\
(0.027)\end{array}$ \\
\hline $30-39$ & 1.181 & $\begin{array}{l}0.169-8.231 \\
(0.867)\end{array}$ & 0127 & $\begin{array}{l}0.005-3.081 \\
(0.205)\end{array}$ \\
\hline $40-49$ & 1.180 & $\begin{array}{l}0.165-8.461 \\
(0.869)\end{array}$ & 0.119 & $\begin{array}{l}0.004-3.175 \\
(0.204)\end{array}$ \\
\hline $50-59$ & 1 & - & 1 & - \\
\hline \multicolumn{5}{|c|}{ Experience (years) } \\
\hline $0-5$ & 0.585 & $\begin{array}{l}0.074-4.597 \\
(0.610)\end{array}$ & 105.536 & $\begin{array}{l}5.278-2.110 \mathrm{E} 3 \\
(0.002)\end{array}$ \\
\hline $6-10$ & 1.224 & $\begin{array}{l}0.149-10.051 \\
(0.851)\end{array}$ & 24.213 & $\begin{array}{l}1.309-447.909 \\
(0.032)\end{array}$ \\
\hline $11-15$ & 1.191 & $\begin{array}{l}0.144-9.823 \\
(0.871)\end{array}$ & 19.903 & $\begin{array}{l}0.989-400.700 \\
(0.051)\end{array}$ \\
\hline $16-20$ & 0.563 & $\begin{array}{l}0.052-6.139 \\
(0.638)\end{array}$ & 10.617 & $\begin{array}{l}0.403-279.375 \\
(0.157)\end{array}$ \\
\hline $21-25$ & 0.910 & $\begin{array}{l}0.082-10.068 \\
(0.939)\end{array}$ & - & - \\
\hline $26-30$ & 1.716 & $0.214-13.736$ & 0.557 & $\begin{array}{l}0.044-7.005 \\
(0.650)\end{array}$ \\
\hline \multicolumn{4}{|c|}{ Marital Status } & - \\
\hline Married & 0.745 & $\begin{array}{l}0.385-1.439 \\
(0.380)\end{array}$ & 0.544 & $\begin{array}{l}0.215-1.381 \\
(0.201)\end{array}$ \\
\hline Unmarried & 1 & - & 1 & - \\
\hline \multicolumn{5}{|c|}{ Health Specialty } \\
\hline $\begin{array}{l}\text { Medical } \\
\text { Doctor }\end{array}$ & 1.602 & $\begin{array}{l}0.614-4.180 \\
(0.336)\end{array}$ & 1.069 & $\begin{array}{l}0.285-4.008 \\
(0.921)\end{array}$ \\
\hline $\begin{array}{l}\text { Veterinary } \\
\text { doctor }\end{array}$ & 0.997 & $\begin{array}{l}0.387-2.568 \\
(0.996)\end{array}$ & 1.427 & $\begin{array}{l}0.379-5.370 \\
(0.599)\end{array}$ \\
\hline $\begin{array}{l}\text { Public } \\
\text { Health } \\
\text { Officer }\end{array}$ & 1.627 & $\begin{array}{l}0.547-4.841 \\
(0.381)\end{array}$ & 1.164 & $\begin{array}{l}0.271-4.998 \\
(0.838)\end{array}$ \\
\hline Nurse & 1.216 & $\begin{array}{l}0.289-5.127 \\
(0.790)\end{array}$ & 0.686 & $\begin{array}{l}0.099-4.765 \\
(0.703)\end{array}$ \\
\hline Pharmacist & 1.308 & $\begin{array}{l}0.292-5.862 \\
(0.726)\end{array}$ & 0.609 & $\begin{array}{l}0.111-3.347 \\
(0.568)\end{array}$ \\
\hline MLS & 2.005 & $\begin{array}{l}0.423-9.517 \\
(0.381)\end{array}$ & - & - \\
\hline Others & 1 & - & 1 & - \\
\hline \multicolumn{5}{|c|}{ Geopolitical zone } \\
\hline $\begin{array}{l}\text { North } \\
\text { Central }\end{array}$ & 1.019 & $\begin{array}{l}0.346-3.001 \\
(0.973)\end{array}$ & 0.426 & $\begin{array}{l}0.082-2.203 \\
(0.309)\end{array}$ \\
\hline Northeast & 1.015 & $\begin{array}{l}0.361-2.852 \\
(0.977)\end{array}$ & 0.387 & $\begin{array}{l}0.081-1.846 \\
(0.234)\end{array}$ \\
\hline Northwest & 1.490 & $\begin{array}{l}0.388-5.721 \\
(0.562)\end{array}$ & 0.585 & $\begin{array}{l}0.088-3.913 \\
(0.580)\end{array}$ \\
\hline Southeast & 35.989 & $\begin{array}{l}3.497-370.412 \\
(0.003)\end{array}$ & 4.172 & $\begin{array}{l}0.260-66.829 \\
(0.313)\end{array}$ \\
\hline Southsouth & 2.414 & $\begin{array}{l}0.676-8.612 \\
(0.175)\end{array}$ & 0.650 & $\begin{array}{l}0.091-4.631 \\
(0.667)\end{array}$ \\
\hline Southwest & 1 & - & 1 & - \\
\hline \multicolumn{5}{|c|}{$\begin{array}{l}\text { To prevent the infection by COVID-19, individuals should avoid going to } \\
\text { crowded places. }\end{array}$} \\
\hline $\begin{array}{l}\text { Strongly } \\
\text { Disagree }\end{array}$ & 1 & 1 & 1 & - \\
\hline Neutral & - & - & 8.6245 & $\begin{array}{l}0.451-164.480 \\
(0.152)\end{array}$ \\
\hline Agree & 2.620 & $\begin{array}{l}0.936-7.33 \\
(0.067)\end{array}$ & 0.776 & $\begin{array}{l}0.213-2.825 \\
(0.701)\end{array}$ \\
\hline $\begin{array}{l}\text { Strongly } \\
\text { agree }\end{array}$ & 6.939 & $\begin{array}{l}2.567-18.759 \\
(<0.001)\end{array}$ & 2.353 & $\begin{array}{l}0.632-8.761 \\
(0.202)\end{array}$ \\
\hline \multicolumn{5}{|c|}{ Nigeria is providing palliative to the poor and less privileged } \\
\hline $\begin{array}{l}\text { Strongly } \\
\text { Disagree }\end{array}$ & 1 & - & 0.307 & $\begin{array}{l}0.046-2.038 \\
(0.222)\end{array}$ \\
\hline Disagree & 0.427 & $\begin{array}{l}0.201-0.909 \\
(0.027)\end{array}$ & 0.139 & $\begin{array}{l}0.020-0.962 \\
(0.046)\end{array}$ \\
\hline
\end{tabular}

Table 2 (continued)

\begin{tabular}{|c|c|c|c|c|}
\hline Variables & $\begin{array}{l}\text { Wearing } \\
\text { of Face } \\
\text { mask }\end{array}$ & $\begin{array}{l}\text { 95\% C.I (P } \\
\text { Value) }\end{array}$ & $\begin{array}{l}\text { Washing } \\
\text { hands, and } \\
\text { social } \\
\text { distancing }\end{array}$ & $\begin{array}{l}\text { 95\% C.I (P } \\
\text { Value) }\end{array}$ \\
\hline Neutral & 0.249 & $\begin{array}{l}0.096-0.643 \\
(0.004)\end{array}$ & 0.254 & $\begin{array}{l}0.031-2.121 \\
(0.206)\end{array}$ \\
\hline Agree & 0.257 & $\begin{array}{l}0.104-0.633 \\
(0.003)\end{array}$ & 0.245 & $\begin{array}{l}0.032-1.849 \\
(0.173)\end{array}$ \\
\hline $\begin{array}{l}\text { Strongly } \\
\text { agree }\end{array}$ & 0.787 & $\begin{array}{l}0.265-2.331 \\
(0.665)\end{array}$ & 1 & - \\
\hline \multicolumn{5}{|c|}{ SARS-CoV-2 is a biological weapon to reduce the human population in Africa } \\
\hline Yes & 1 & - & 1 & $\begin{array}{l}0.350-2.619 \\
(0.932)\end{array}$ \\
\hline No & 1.255 & $\begin{array}{l}0.450-3.506 \\
(0.664)\end{array}$ & 9.787 & $\begin{array}{l}2.379-40.265 \\
(0.002)\end{array}$ \\
\hline \multicolumn{5}{|c|}{$\begin{array}{l}\text { Do you have confidence that medical scientists can win the battle against the } \\
\text { COVID-19 pandemic? }\end{array}$} \\
\hline Yes & 5.769 & $\begin{array}{l}1.635-20.354 \\
(0.006)\end{array}$ & 1.159 & $\begin{array}{l}0.186-7.211 \\
(0.874)\end{array}$ \\
\hline No & 1 & - & 1 & - \\
\hline \multicolumn{5}{|c|}{ Adequate PPE at the place of work } \\
\hline Yes & 1.309 & $\begin{array}{l}0.595-2.882 \\
(0.504)\end{array}$ & 1 & - \\
\hline No & 1 & - & 0.880 & $\begin{array}{l}0.263-2.952 \\
(0.837)\end{array}$ \\
\hline
\end{tabular}

MLST $=$ Medical Laboratory Scientist; OR = Odd Ratio; PPE; personal protective equipment.

odds of $14.15,10.38$ and 17.82 respectively than the older age group 50-59 (reference, OR $=1$ ). The married HCWs were three times more likely to be concerned about being infected with SARS-CoV-2 than the single category $(\mathrm{OR}=3.39 ; 95 \%$ C.I $=1.03-11.19$; $\mathrm{p}=0.045)$. For health speciality, the risk perception analysis the Medical Laboratory Scientist (MLS) were less likely to be anxious that they would become infected with SARS-CoV-2 compare with others (OR $=0.017 ; 95 \%$ C.I: $0.002-0.15 ; \mathrm{P}=0.0001$ ). Also, they were less concerned that their family members would be at risk of contracting the infection than the other HCWs (OR $=0.047 ; 95 \%$ C.I: $0.006-0.388 ; \mathrm{p}=0.0005)$. Healthcare workers from Northcentral had four times more likelihood of risk of SAR-CoV-2 infection than the reference S.W. region, $(O R=1)$. Similarly, the HCWs from the North east had six times the likelihood of being at risk of SARS-CoV-2 infection than the S.W. region.

Healthcare workers who were neutral about whether Nigeria should seek foreign aids for the COVID-19 outbreak were about 13 times more likely ( $\mathrm{OR}=12.519 ; 95 \%$ C.I: $2.193-71.457 ; \mathrm{P}=0.004)$ to be a concern that they will be infected with SARS-CoV-2. Likewise, they were about six more (OR $=5.885 ; 95 \%$ C.I: $1.634-20.973 ; p=0.007)$ anxious about their families becoming infected with SARS-CoV-2 as a result of their occupation. HCWs who were not aware that they have life insurance were about six times more likely (OR $=5.370$; 95\% C.I: 1.799-16.636; $\mathrm{p}$ $=0.010$ ) to be concerned that they will be infected with SARS-CoV-2. Also, HCWs who were not aware that they have life insurance were more (OR $=7.624 ; 95 \%$ C.I: $1.373-42.320 ; \mathrm{p}=0.020)$ anxious that their families will become infected with SARS-CoV-2. Similarly, HCWs who were aware that they have life insurance were more (OR $=3.757 ; 95 \%$ C.I: $1.580-8.931 ; \mathrm{p}=0.003)$ concerned that their families were at risk of COVID-19 infection (Table 3).

\section{Discussion}

Ensuring the safety of HCWs is not only essential for the protection and prevention of nosocomial transmission of SARS-COV-2 but prevent community spread of the virus ${ }^{8}$ the battle against COVID-19 pandemic require both the effort of HCWs, governments and non-governmental organization and their partners at all levels. On the part of the government, there is a need for the provision of minimum standard infrastructure, provision emergency relief for the vulnerable, policy formulation, and provisions of essential equipment such as diagnostic 
Table 3

Anxiety for risk of COVID-19 Infection by Healthcare workers in Nigeria.

\begin{tabular}{|c|c|c|c|c|}
\hline \multirow[b]{2}{*}{ Variables } & \multicolumn{4}{|l|}{ Anxiety, OR } \\
\hline & $\begin{array}{l}\text { Risk of } \\
\text { COVID-19 } \\
\text { due to } \\
\text { Profession }\end{array}$ & $\begin{array}{l}95 \% \mathrm{C} \cdot \mathrm{I}(\mathrm{P} \\
\text { Value) }\end{array}$ & $\begin{array}{l}\text { The } \\
\text { family are } \\
\text { at Risk of } \\
\text { SARS- } \\
\text { COV-2 }\end{array}$ & $\begin{array}{l}\text { 95\% C.I (P } \\
\text { Value) }\end{array}$ \\
\hline \multicolumn{5}{|l|}{ Gender } \\
\hline Male & 1.263 & $\begin{array}{l}0.429-3.716 \\
(0.672)\end{array}$ & 1.525 & $\begin{array}{l}0.672-3.459 \\
(0.312)\end{array}$ \\
\hline Female & 1 & & 1 & - \\
\hline \multicolumn{5}{|l|}{ Age group } \\
\hline $20-29$ & 2.777 & $\begin{array}{l}0.126-61.345 \\
(0.518)\end{array}$ & 14.148 & $\begin{array}{l}1.141-175.456 \\
(0.039)\end{array}$ \\
\hline $30-39$ & 3.028 & $\begin{array}{l}0.198-46.240 \\
(0.426)\end{array}$ & 10.378 & $\begin{array}{l}1.086-99.158 \\
(0.042)\end{array}$ \\
\hline $40-49$ & 8.933 & $\begin{array}{l}0.511-156.194 \\
(0.134)\end{array}$ & 17.817 & $\begin{array}{l}1.555-204.153 \\
(0.021)\end{array}$ \\
\hline $50-59$ & 1 & - & 1 & - \\
\hline \multicolumn{5}{|c|}{ Experience (years) } \\
\hline $0-5$ & 0.217 & $\begin{array}{l}0.010-4.559 \\
(0.326)\end{array}$ & 0.356 & $\begin{array}{l}0.041-3.060 \\
(0.346)\end{array}$ \\
\hline $6-10$ & 0.298 & $\begin{array}{l}0.013-6.667 \\
(0.445)\end{array}$ & 0.834 & $\begin{array}{l}0.097-7.150 \\
(0.868)\end{array}$ \\
\hline $11-15$ & 0.263 & $\begin{array}{l}0.012-5.797 \\
(0.398)\end{array}$ & 0.708 & $\begin{array}{l}0.073-6.870 \\
(0.766)\end{array}$ \\
\hline $16-20$ & 0.056 & $\begin{array}{l}0.001-2.243 \\
(0.126)\end{array}$ & 0.274 & $\begin{array}{l}0.015-5.036 \\
(0.383)\end{array}$ \\
\hline $21-25$ & 0.455 & $\begin{array}{l}0.014-14.552 \\
(0.656)\end{array}$ & 0.542 & $\begin{array}{l}0.046-6.327 \\
(0.625)\end{array}$ \\
\hline $26-30$ & - & - & - & - \\
\hline $\begin{array}{l}31+ \\
\text { Marital Sta }\end{array}$ & 1 & & 1 & - \\
\hline Married & 3.387 & $\begin{array}{l}1.025-11.185 \\
(0.045)\end{array}$ & 1.435 & $\begin{array}{l}0.622-3.312 \\
(0.397)\end{array}$ \\
\hline Unmarried & 1 & - & 1 & - \\
\hline \multicolumn{5}{|c|}{ Health Specialty } \\
\hline $\begin{array}{l}\text { Medical } \\
\text { Doctor }\end{array}$ & 3.108 & $\begin{array}{l}0.534-18.094 \\
(0.207)\end{array}$ & 1.730 & $\begin{array}{l}0.500-5.991 \\
(0.387)\end{array}$ \\
\hline $\begin{array}{l}\text { Veterinary } \\
\text { doctor }\end{array}$ & 1.097 & $\begin{array}{l}0.242-4.981 \\
(0.904)\end{array}$ & 1.291 & $\begin{array}{l}0.367-4.455 \\
(0.690)\end{array}$ \\
\hline $\begin{array}{l}\text { Public } \\
\text { Health } \\
\text { Officer }\end{array}$ & 4.047 & $\begin{array}{l}0.417-39.268 \\
(0.228)\end{array}$ & 1.118 & $\begin{array}{l}0.255-4.900 \\
(0.882)\end{array}$ \\
\hline Nurse & 0.496 & $\begin{array}{l}0.062-3.947 \\
(0.508)\end{array}$ & 1.015 & $\begin{array}{l}0.174-5.933 \\
(0.987)\end{array}$ \\
\hline Pharmacist & 0.239 & $\begin{array}{l}0.030-1.1 .921 \\
(0.178)\end{array}$ & 1.761 & $\begin{array}{l}0.158-19.592 \\
(0.645)\end{array}$ \\
\hline MLS & 0.017 & $\begin{array}{l}0.002-0.154 \\
(0.0001)\end{array}$ & 0.047 & $\begin{array}{l}0.006-0.388 \\
(0.005)\end{array}$ \\
\hline Others & 1 & - & 1 & - \\
\hline \multicolumn{5}{|c|}{ Geopolitical zone } \\
\hline $\begin{array}{l}\text { North } \\
\text { Central }\end{array}$ & 1.125 & $\begin{array}{l}0.168-7.511 \\
(0.903)\end{array}$ & 4.615 & $\begin{array}{l}1.072-19.859 \\
(0.040)\end{array}$ \\
\hline Northeast & 1.336 & $\begin{array}{l}0.218-8.172 \\
(0.754)\end{array}$ & 6.753 & $\begin{array}{l}1.852-24.623 \\
(0.004)\end{array}$ \\
\hline Northwest & 0.2668 & $\begin{array}{l}0.032-2.231 \\
(0.223)\end{array}$ & 3.170 & $\begin{array}{l}0.639-15.717 \\
(0.158)\end{array}$ \\
\hline Southeast & 0.301 & $\begin{array}{l}0.033-2.751 \\
(0.288)\end{array}$ & 1.014 & $\begin{array}{l}0.193-5.339 \\
(0.987)\end{array}$ \\
\hline Southsouth & 1.645 & $\begin{array}{l}0.152-17.813 \\
(0.682)\end{array}$ & 2.319 & $\begin{array}{l}0.494-10.880 \\
(0.286)\end{array}$ \\
\hline Southwest & 1 & - & & \\
\hline \multicolumn{5}{|c|}{ Nigeria to seek foreign aid in terms of equipment and professionals } \\
\hline $\begin{array}{l}\text { Strongly } \\
\text { Disagree }\end{array}$ & 1.569 & $\begin{array}{l}0.277-8.868 \\
(0.611)\end{array}$ & 2.123 & $\begin{array}{l}0.513-8.785 \\
(0.299)\end{array}$ \\
\hline Disagree & 0.987 & $\begin{array}{l}0.213-4.570 \\
(0.986)\end{array}$ & 1.421 & $\begin{array}{l}0.420-4.811 \\
(0.572)\end{array}$ \\
\hline Neutral & 12.519 & $\begin{array}{l}2.193-71.457 \\
(0.004)\end{array}$ & 5.885 & $\begin{array}{l}1.634-20.973 \\
(0.007)\end{array}$ \\
\hline Agree & 1.237 & $\begin{array}{l}0.375-4.080 \\
(0.727)\end{array}$ & 2.399 & $\begin{array}{l}0.872-6.603 \\
(0.090)\end{array}$ \\
\hline $\begin{array}{l}\text { Strongly } \\
\text { agree }\end{array}$ & 1 & - & 1 & - \\
\hline
\end{tabular}

Table 3 (continued)

\begin{tabular}{|c|c|c|c|c|}
\hline \multirow[b]{2}{*}{ Variables } & \multicolumn{4}{|c|}{ Anxiety, OR } \\
\hline & $\begin{array}{l}\text { Risk of } \\
\text { COVID-19 } \\
\text { due to } \\
\text { Profession }\end{array}$ & $\begin{array}{l}\text { 95\% C.I (P } \\
\text { Value) }\end{array}$ & $\begin{array}{l}\text { The } \\
\text { family are } \\
\text { at Risk of } \\
\text { SARS- } \\
\text { COV-2 }\end{array}$ & $\begin{array}{l}\text { 95\% C.I (P } \\
\text { Value) }\end{array}$ \\
\hline \multicolumn{5}{|c|}{ Nigeria is providing palliative to the poor and less privileged } \\
\hline $\begin{array}{l}\text { Strongly } \\
\text { Disagree }\end{array}$ & 1 & - & 1 & - \\
\hline Disagree & 17.334 & $\begin{array}{l}3.819-78.685 \\
(0.0001)\end{array}$ & 1.590 & $\begin{array}{l}0.616-4.110 \\
(0.338)\end{array}$ \\
\hline Neutral & 2.394 & $\begin{array}{l}0.498-11.517 \\
(0.276)\end{array}$ & 0.888 & $\begin{array}{l}0.253-3.118 \\
(0.853)\end{array}$ \\
\hline Agree & 3.998 & $\begin{array}{l}0.985-16.223 \\
(0.053)\end{array}$ & 3.447 & $\begin{array}{l}0.908-13.082 \\
(0.069)\end{array}$ \\
\hline $\begin{array}{c}\text { Strongly } \\
\text { agree }\end{array}$ & 11.325 & $\begin{array}{l}1.766-72.636 \\
(0.010)\end{array}$ & 3.477 & $\begin{array}{l}0.775-15.599 \\
(0.104)\end{array}$ \\
\hline \multicolumn{5}{|c|}{ Proper life insurance cover for HCWs } \\
\hline Yes & 3.366 & $\begin{array}{l}0.573-19.773 \\
(0.179)\end{array}$ & 3.757 & $\begin{array}{l}1.580-8.931 \\
(0.003)\end{array}$ \\
\hline No & 5.370 & $\begin{array}{l}1.799-16.028 \\
(0.003)\end{array}$ & 7.624 & $\begin{array}{l}1.373-42.320 \\
(0.020)\end{array}$ \\
\hline Not Sure & 1 & - & 1 & - \\
\hline \multicolumn{5}{|c|}{ Adequate PPE at the place of work } \\
\hline Yes & 1 & - & 1 & - \\
\hline No & 1.041 & $\begin{array}{l}0.333-3.257 \\
(0.945)\end{array}$ & 1.339 & $\begin{array}{l}0.487-3.683 \\
(0.571)\end{array}$ \\
\hline \multicolumn{5}{|c|}{ Nigeria is adequately prepared to contain COVID-19 } \\
\hline True & 0.447 & $\begin{array}{l}0.124-1.610 \\
(0.218)\end{array}$ & 0.886 & $\begin{array}{l}0.297-2.638 \\
(0.827)\end{array}$ \\
\hline False & 1 & - & 1 & - \\
\hline
\end{tabular}

tools, personal protection equipment (PPE), and environmental protection. $^{16}$

Healthcare workers in Nigeria are provided with health insurance as part of terms of employment under the national health insurance scheme (NHIS), which is optional. ${ }^{17}$ However, the scheme is not effective in the coverage of many health care issues, emergencies, and even life insurance among healthcare workers is not guaranteed. Moreover, the fact that the Majority of the HCWs agreed that there is no provision of insurance is in line with the existing situation.

The reason for the high proportion of respondents who held that Veterinary doctor is part of the presidential task force because of the recent campaigns for One Health Initiative and Global health strategy for the control of emerging diseases by the World Health Organization. ${ }^{18-20}$ Secondly, the result may have been influenced by the high proportion of veterinary healthcare workers' participation in the study. Also, the Federal Government of Nigeria, in collaboration with Nigerian Center for Disease Control and Prevention (NCDC), emphasized the need for a multispectral approach and centralized coordination during the response to COVID-19. ${ }^{5}$

A significant number of respondents agreed that FGN should seek foreign intervention to respond to the COVID-19 outbreak. This response may be related to the socioeconomic factors, fear, and uncertainty of SARS-CoV-2 as a novel virus. The country may require foreign intervention such as training of isolation center staff on IPC and case management to prevent the spread and to manage the confirmed cases of COVID-19 as part of capacity building. Also, procurement of crucial IPC supplies to curtail the chain of transmission, laboratory test kits, and reagents to increase testing capacity and attaining the recommended positivity rate of $<5$. $^{21}$

In an emergency, provision of relief to the vulnerable is key to ensuring an effective response to an outbreak due to compliance. The provision of reliefs by the government is consistent with the palliative measures adopted by the United States of America and other developed countries of the World. ${ }^{16}$ Palliative measures are particularly essential during lockdown where people are not allowed to go out for business and other anthropogenic activities. Moreover, this could lead to a lack of 
sustainability for livelihood.

It is a fact in the Nigerian health care system that those with good working experience are expected to observe rules and regulations regarding disease prevention. However, our findings show that willingness to abide by the protective measures among the HCWs decreases with increasing years of working experience. Therefore, the duration of service could be a risk factor of COVID-19 among HCWs due to inadequate protective behavior among those with long years of experience. Our finding was consistent with the previous report. ${ }^{22}$ On the contrary, our finding also revealed that the protective behavior of HCWs towards COVID-19 increases with the increasing age of HCWs in a directly proportional relationship. Those with 20-29 years of age were less likely to use protective measures against COVID-19 than those within the age bracket $50-59$ years.

Though it appears that HCWs from the southeast region had more likelihood to use protective measures like a face mask, gloves, and other PPE than those from the southwest region, but this is contrasting in the sense that Southwest Nigeria has more literacy than the southeast. Other factors that may be responsible for this disparity be cultural or social beliefs. $^{23,24}$

We found a significant association between the opinion of HCWs to avoid the large crowd and the use of face mask when leaving home in that those with the opinion were more likely to use face mask than those who strongly disagree. The reason for this different opinion among HCWs with regards to the use of face mask and avoidance of large crowd (social distance) could be due to effect rumour, misinformation through social media, myths, and social beliefs. ${ }^{25}$ Similarly, families of HCWs who thought that COVID-19 is a biological weapon were less likely to observe preventive measures against COVID-19. All these findings are clear evidence of misconception of COVID-19 among HCWs. The risk assessment of the country was considered high. Moreover, rumours facilitate the spread of infodemic. These, collectively, may have negative impacts on the national response activities. ${ }^{26}$

In this study, we found that the majority of the HCWs within the age category of 20-49 years were more concerned about the risk of SARSCOV-2 infection than the elderly age groups (50-59 years). This age group (20-49 years) was expected to have the highest risk of infection due to exposure and activeness compare to the reference group. Though, the age group 30-39 years perceived to have had moderate anxiety compared to the group 40-49 years, the same group may be considered a transition age between youthfulness and adulthood were thought to be at higher risk of infection compared to the other age groups because of the nature of being youthful ${ }^{13,27}$

Healthcare workers are at the frontlines in emergency response activities, likewise in the COVID-19 pandemic. Hence, the married HCWs are more likely to infect their partners or family members and vice versa than the unmarried. For instance, an HCWs who were infected with SARS-COV-2 serve as sources of infection to their partners and family members. Therefore it is natural that the married HCWs would be more likely to be concerned that they will become infected with SARS-COV-2 than the unmarried.

\section{Conclusions}

The national preparedness and response to the COVID-19 outbreak in Nigeria were inadequate in the initial statge of the pandemic. Majority of the HCWs agreed that palliatives were not distributed to the poor and the less privileged in their communities. The demographic factors of HCWs in this study were associated with preventive behavior against COVID-19. However, the age category 20-26 demonstrated less likelihood of observing preventive measures against the COVID-19. Healthcare workers were worried that they might become infected with SARS$\mathrm{CoV}-2$. They also expressed fear that their families were at risk of COVID-19 infection.

\section{Authors' contributions}

Francis Enenche Ejeh conceived and designed the study. Francis Enenche Ejeh; Adamu Saidu Saleh; Samuel Owoicho; Laura Madukaji; Kenneth O Okon conducted research, provided research materials, and collected and organized data. Francis Enenche Ejeh; Adamu Saidu Saleh; Kenneth O Okon analyzed and interpreted data. Francis Enenche Ejeh; Adamu Saidu Saleh; Samuel Owoicho; Laura Madukaji; Kenneth O Okon wrote the initial and final draft of an article, and provided logistic support. All authors have critically reviewed and approved the final draft and are responsible for the content and similarity index of the manuscript.

\section{Declaration of competing interest}

There is no conflict of interest regarding the publication of this paper.

\section{Acknowledgements}

The authors are indebted to thank the healthcare workers in Nigeria who spared their valuable time to respond to this survey questions. We are very thankful to the other senior colleagues who helped in making this study a successful one. We thank Prof. M. B Abubakar of Virology Laboratory, the University of Maiduguri, for his assistance.

\section{References}

1 Zhu $\mathrm{H}$, Wei L, Niu P, et al. The novel coronavirus outbreak in Wuhan, China Development and validation of knowledge, attitude and practice questionnaire for prevention of respiratory tract infections among Malaysian Hajj pilgrims. Glob Heal Res Policy. 2020;5(6):1-3.

2 Sohrabi C, Alsafi Z, O'Neill N, et al. World Health Organization declares global emergency: a review of the 2019 novel coronavirus (COVID-19). Int J Surg. 2020;76 (3):71-76.

3 WHO. Coronavirus disease (COVID-19) pandemic; 2020. Update https://www.who. int/emergencies/diseases/novel-coronavirus-2019?gclid=Cj0KCQjwrIf3BRD1ARIs AMuugNshiIvJW4TtfuTTZWfSDlnCnxyATbeoJSBqZbZXFCz6ezS2aqRwSj0aAr oiEALw_wcB. Accessed June 6, 2020.

4 Worldometer. COVID-19 update; 2020. https://www.worldometers.info/coronav irus/?utm_campaign=homeAdvegas 1 ?.

5 NCDC. COVID-19 updates; 2020. https://covid19.ncdc.gov.ng/.

6 Guo YR, Cao QD, Hong ZS, et al. The origin, transmission and clinical therapies on coronavirus disease 2019 (COVID-19) outbreak- A n update on the status. Mil Med Res. 2020;7(11):1-10.

7 Kannan S, Shaik Syed Ali P, Sheeza A, Hemalatha K. COVID-19 (Novel Coronavirus 2019) - recent trends. Eur Rev Med Pharmacol Sci. 2020;24(4):2006-2011.

8 Barati M, Bashirian S, Jenabi E, et al. Factors associated with preventive behaviours of COVID-19 among hospital staff in Iran in 2020: an application of the protection motivation theory. J Hosp Infect. 2020;105:430-433.

9 Chou R, Dana T, Buckley DI, Selph S, Fu R, Totten AM. Epidemiology of and risk factors for coronavirus infection in health care workers: a living rapid review. Ann Intern Med. 2020:1-17.

10 Mhango M, Dzobo M, Chitungo I, Dzinamarira T. COVID-19 risk factors among health workers: a rapid review. Saf Heal atWork. 2020;1-4.

11 Ramakrishnan D. Covid-19 and face masks - to use or not to use!. Indian J Community Health. 2020;78:7828-7832.

12 Wu YC, Chen CS, Chan YJ. The outbreak of COVID-19: an overview. J Chin Med Assoc. 2020;83(3):217-220.

13 He F, Deng Y, Li W. Coronavirus disease 2019: what we know? J Med Virol. 2020;92 (7):719-725.

14 Chinese Center for Disease Control and Prevention. The epidemiological characteristics of an outbreak of 2019 novel coronavirus diseases (COVID-19) China, 2020 the novel coronavirus pneumonia emergency response epidemiology team. CCDC Wkly. 2020;2(8):5.

15 Taber KS. The use of cronbach's alpha when developing and reporting research instruments in science education. Res Sci Educ. 2018;48:1273-1296.

16 National Center for Immunization, Respiratory Diseases, Division of Viral Diseases. Interim Infection Prevention and Control Recommendations for Patients with Suspected or Confirmed Coronavirus Disease 2019 (COVID-19) in Healthcare Settings. CDC; 2020.

17 Obalum D, Fiberesinma F. National health insurance scheme: overview. Niger Postgrad Med J. 2012;19(3):167-174.

18 Thoen CO, Lobue PA, Enarson DA, Kaneene JB, de Kantor IN. Tuberculosis: a reemerging disease in animals and humans. Int J Tubercul Lung Dis. 2010;45(1): $135-181$.

19 Thoen CO, Kaplan B, Thoen TC, Gilsdorf MJ, Shere JA. Zoonotic tuberculosis. A comprehensive one health approach. Medicina. 2016;76(3):159-165. 
20 World Health Organization (WHO). Naming the Coronavirus Disease (COVID-19) and the Virus that Causes it". World Health Organization. The ICTV's Page Is Here: International Committee on Taxonomy of Viruses (ICTV). World Heal Organ; 2020.

21 AfrCDC. Recommendations for stepwise response to COVID-19. https://africacdc.or $\mathrm{g} /$ download/recommendations-for-stepwise-response-to-covid-19/\%0A; 2020.

22 Zhong BL, Luo W, Li HM, et al. Knowledge, attitudes, and practices towards COVID19 among Chinese residents during the rapid rise period of the COVID-19 outbreak: a quick online cross-sectional survey. Int J Biol Sci. 2020;16(10):1745-1752.

23 Bruns DP, Kraguljac NV, Bruns TR. COVID-19: facts, cultural considerations, and risk of stigmatization. J Transcult Nurs. 2020;31(4):326-332.

24 Muurlink OT, Taylor-Robinson AW. COVID-19: cultural predictors of gender differences in global prevalence patterns. Front Public Heal. 2020. https://doi.org/ 10.3389/fpubh.2020.00174.
25 Saqlain M, Munir MM, Rehman Sur, et al. Knowledge, attitude, practice and perceived barriers among healthcare professionals regarding COVID-19: a Crosssectional survey from Pakistan. J Hosp Infect. 2020;105(3):419-423.

26 AfrCDC. Africa CDC guidance for assessment, monitoring, and movement restrictions of people at risk for COVID-19 in Africa. https://au.int/sites/default/files/do cuments/38260-doc-africa_cdc_guidance_for_assessment_monitoring_and_movement_ restrictions_of_people_at_risk_for_covid-19_in_africa.pdf; 2020.

27 Chen Y, Jin YL, Zhu LJ, et al. The network investigation on knowledge, attitude and practice about COVID-19 of the residents in Anhui Province. Zhonghua Yufang Yixue Zazhi. 2020;54(4):367-373. 